ISSN: 2302-8556

E-Jurnal Akuntansi Universitas Udayana

Vol.24.3.September (2018): 1737-1767

DOI: https://doi.org/10.24843/EJA.2018.v24.i03.p04

\title{
Pengaruh Kinerja Lingkungan dan Komponen Good Corporate Governance pada Nilai Perusahaan yang Terdaftar di BEI
}

\author{
Agung Dewi Kurnia ${ }^{1}$ \\ Pradnyantha Wirasedana ${ }^{2}$
}

${ }^{1}$ Fakultas Ekonomi dan Bisnis Universitas Udayana (Unud), Bali, Indonesia
email: agungdewikurnia12@gmail.com/Telp: 087860640889
${ }^{2}$ Fakultas Ekonomi dan Bisnis Universitas Udayana (Unud), Bali, Indonesia

\section{ABSTRAK}

Nilai perusahaan merupakan suatu keadaan yang telah dicapai oleh perusahaan sebagai kepercayaan dari masyarakat pada perusahaan tersebut. Perusahaan di dalam memaksimalkan perusahannya harus memperhatikan tanggung jawab lingkungan dan tata kelolanya. Tujuan penelitian adalah untuk mengetahui pengaruh kinerja lingkungan dan komponen good corporate governance pada nilai perusahaan. Sampel pada penelitian ini dipilih menggunakan metode purposive sampling, dan diperoleh sampel sebanyak 43 perusahaan yang terdaftar di BEI tahun 2014 - 2016. Kinerja lingkungan diukur menggunakan peringkat PROPER, komponen good corporate governance diukur menggunakan kepemilikan manajerial, kepemilikan institusional, komite audit dan dewan komisaris independen. Teknik analisis data yang digunakan adalah teknik analisis regresi linear berganda. Hasil pengujian menunjukkan bahwa bahwa kepemilikan manajerial, kepemilikan institusional, dan komite audit tidak berpengaruh pada nilai perusahaan. Sedangkan, kinerja lingkungan dan dewan komisaris independen berpengaruh positif pada nilai perusahaan.

Kata Kunci: kinerja lingkungan, good corporate governance, nilai perusahaan

\section{ABSTRACT}

Corporate value is the condition achieved by the company as form of trust from the community towards the company. Companies in their maximization should take into their environmental responsibilities and corporate governance. The purpose of this research is to examine the effect of environmental performance and the components of good corporate governance on the corporate value. The sample in this research is selected using the purposive sampling method, and obtained 43 companies listed in the IDX during 2014 2016. Environmental performance is measured utilizing PROPER's rank, the components of good corporate governance are measured through managerial ownership, institutional ownership, audit committee and the board of independent commissionaires. The data analysis technique utilized is the multiple linear regression analysis technique. The research result shows that managerial ownership, institutional ownership, and audit committee don't influence corporate value. Environmental performance and the board of independent commissionaires have positive effect on the corporate value.

Keywords: environmental performance, good corporate governance, corporate value 
Agung Dewi Kurnia dan Pradnyantha Wirasedana. Pengaruh...

\section{PENDAHULUAN}

Tujuan perusahaan adalah untuk mendapatkan laba yang tinggi (Aghashahi et al., 2013). Tujuan lainnya adalah untuk memperkaya kondisi keuangan pemilik perusahaan atau para pemegang saham, dan untuk memaksimalkan nilai perusahaan (Danarwati, 2013). Sebenarnya, tidak banyak perbedaan dari tujuan perusahaan tersebut, hanya saja penekanan di satu perusahaan terhadap perusahaan lainnya berbeda (Sitepu, 2015). Indriani, Darmawan dan Nurhawa (2014) menyatakan bahwa investor tertarik untuk melakukan investasi pada suatu perusahaan karena adanya keterbukaan informasi yang diberikan oleh perusahaan dengan tujuan utamanya yaitu memperoleh return.

Nilai perusahaan sendiri diukur menggunakan rasio Tobin's $Q$. Tobin's $Q$ merupakan indikator yang dapat menunjukkan suatu performa manajemen dalam mengelola aktivitas perusahaan untuk mendukung nilai perusahaan. Jika nilai perusahaan terjamin, tentu saja akan berpengaruh pada going concern perusahaan (Dewi, 2016). Namun, di dalam upaya memaksimalkan nilai perusahaan seringkali terjadi konflik perbedaan kepentingan (agency conflict). Salah satu kondisi yang menimbulkan konflik keagenan adalah ketidakmerataan informasi (information asymmetry) yang mengakibatkan terbukanya peluang manajer melakukan tindakan yang menguntukngkan bagi dirinya (Budiharjo, 2016). Adanya asimetri informasi pada laporan keuangan disebabkan karena manajer lebih mengetahui informasi internal dan prospek perusahaan dibandingkan dengan pemilik dan stakeholder lainnya (Barus dan Setiawati, 2015). Karena adanya celah yang dapat dimanfaatkan oleh manajer, maka dibutuhkan suatu mekanisme pengendalian yang dapat 
ISSN: 2302-8556

E-Jurnal Akuntansi Universitas Udayana

Vol.24.3.September (2018): 1737-1767

menyatukan perbedaan kepentingan para pengguna informasi laporan keuangan. Mekanisme yang digunakan untuk mewujudkan kinerja perusahaan yang baik dalam rangka meningkatkan nilai perusahaan adalah menerapkan Good Corporate Governance (Perdana, 2014).

Good Corporate Governance sangat penting untuk perusahaan karena hal tersebut memegang peranan vital dalam pengembangan organisasi perusahaan di negara-negara berkembang (Narwal dan Jindal, 2015) karena tujuan dari Corporate Governance adalah "untuk menciptakan nilai tambah bagi semua pihak yang berkepentingan (stakeholders)." Berbagai macam kasus kecurangan yang dilakukan oleh pihak manajer pada laporan keuangan dilakukan untuk menarik minat investor ataupun kreditor untuk menanamkan modalnya kepada perusahaan (Dewi dan Suardana, 2015). Hal tersebut memicu para pengguna laporan keuangan melakukan kesalahan dalam mengambil keputusan, sehingga hal tersebut menyebabkan nilai perusahaan menjadi berkurang (Siallagan dan Machfoeds, 2006).

Perusahaan-perusahaan yang menjalankan kegiatan bisnisnya akan bergantung pada seberapa baik kinerja perusahaan yang bukan hanya melihat kinerja keuangan perusahaan saja, tetapi bagaimana perusahaan juga memberikan kontribusi positif kepada lingkungan hidup dan lingkungan sosialnya yang tidak terlepas dari kegiatan untuk meningkatkan produktivitas dan efisiensi perusahaan itu sendiri (Kusumawardani dan Sudana, 2017). Semakin baik tanggung jawab lingkungan untuk menjaga kelestarian lingkungan yang dilakukan oleh perusahaan, maka citra perusahaan akan semakin baik. Investor akan lebih tertarik pada 
perusahaan yang memiliki citra baik di masyarakat, karena berpengaruh pada going concern perusahaan (Hariati dan Rihatiningtyas, 2015). Namun, sering kali perusahaan dalam meningkatkan produktivitas dan efisiensinya justru berakibat pada perusakan lingkungan seperti penggundulan hutan, pencemaran udara, pencemaran air dan lainnya (Suaryana, 2011).

Permasalahan lingkungan di Indonesia adalah suatu hal yang tidak bisa diabaikan begitu saja. Seperti yang ditulis oleh Rahmatwati (2017) pada berita harian online Kompasiana, salah satu isu permasalahan lingkungan yang sedang dihadapi adalah pembangunan pabrik baru oleh PT Semen Gresik (Persero) Tbk di Kabupaten Pati, Jawa Tengah. Konflik mulai muncul ketika perusahaan mencoba melakukan pembangungan pabrik untuk kepentingan komersialnya sedangkan masyarakat yang berada di daerah sekitar kawasan menolak perlakuan perusahaan karena sumber pendapatan masyarakat berasal dari kekayaan sumber daya alam. Perusahaan yang memberikan kontribusi yang banyak di dalam kegiatan lingkungannya, berarti semakin banyak pula yang harus diungkapkan mengenai kinerja lingkungan dalam laporan tahunannya. Hal ini mencerminkan transparansi yang dilakukan oleh perusahaan di dalam melakukan tanggung jawabnya sehingga masyarakat akan menjadi tahu seberapa besar andil dan peran perusahaan menjaga lingkungannya (Oktalia, 2014).

Kinerja lingkungan dapat dinilai melalui Program Penilaian Peringkat Kinerja Perusahaan dalam Pengelolaan Lingkungan Hidup (PROPER) oleh Kementrian Lingkungan Hidup (KLH). Melalui PROPER, kinerja lingkungan perusahaan diukur dengan menggunakan warna, mulai dari yang terbaik yaitu emas, 
hijau, biru, merah hingga yang paling buruk yaitu hitam. Peringkat PROPER akan membantu masyarakat untuk lebih mudah mengetahui tingkat pengelolaan pada perusahaan (Rakhiemah dan Agustia, 2009). Semakin baik peringkat yang dimiliki perusahaan, itu artinya semakin baik bentuk tanggung jawab perusahaan terhadap lingkungan hidup, dimana hal ini dapat meningkatkan nilai perusahaan sehingga menarik minat investor untuk berinvestasi pada perusahaan yang memiliki legitimasi di masyarakat. Penelitian yang dilakukan oleh Tjahjono (2013) menemukan bahwa Kinerja lingkungan tidak memiliki pengaruh terhadap nilai perusahaan. Ini disebabkan bahwa nilai perusahaan dipengaruhi oleh berbagai faktor. Sedangkan, penelitian yang dilakukan oleh Hariati dan Rihatiningtyas (2015) menemukan bahwa kinerja lingkungan berpengaruh positif terhadap nilai perusahaan. Penelitian yang dilakukan oleh Wida dan Suartana (2014) serta Rahmatia dan Andayani (2015) menemukan bahwa kepemilikan manajerial tidak memiliki pengaruh terhadap nilai perusahaan, akan tetapi di sisi lain kepemilikan institusional memiliki pengaruh positif terhadap nilai perusahaan. Berbeda halnya dengan penelitian yang dilakukan oleh Susanti dan Mildawati (2014) menemukan bahwa kepemilikan manajerial berpengaruh positif terhadap nilai perusahaan, namun kepemilikan institusional tidak memiliki pengaruh terhadap nilai perusahaan.

Penelitian lain yang dilakukan oleh Kusumaningtyas (2014) menemukan bahwa komite audit berpengaruh positif terhadap nilai perusahaan. Sedangkan, penelitian yang dilakukan oleh Muryati dan Suardikha (2014) menemukan bahwa komite audit tidak berpengaruh terhadap nilai perusahaan. Penelitian yang 
Agung Dewi Kurnia dan Pradnyantha Wirasedana. Pengaruh...

dilakukan oleh Hartoyo (2016) mengenai good corporate governance menemukan bahwa komisaris independen berpengaruh negatif terhadap nilai perusahaan. Sedangkan, penelitian yang dilakukan oleh Dianawati dan Siti (2016) menemukan bahwa Good Corporate Governance (GCG) yang diukur melalui dewan komisaris independen memiliki pengaruh positif terhadap nilai perusahaan. Pemilihan nilai perusahaan manufaktur sebagai objek penelitian dikarenakan perusahaan manufaktur memerlukan sumber dana jangka panjang yang diperoleh dari investasi saham oleh para investor untuk membiayai kegiatan operasional perusahaan sehingga hal ini tentu saja mempengaruhi niali perusahaan (Herawaty, 2008).

Berdasarkan latar belakang masalah yang telah diuraikan, dapat dirumuskan masalah penelitian yaitu apakah kinerja lingkungan, kepemilikan manajerial, kepemilikan institusional, komite audit dan dewan komisaris berpengaruh pada nilai perusahaan manufaktur yang terdaftar di Bursa Efek Indonesia (BEI) tahun 2014 - 2016. Sesuai dengan pokok permasalahan yang dirumuskan, maka yang menjadi tujuan di dalam penelitian ini adalah untuk mengetahui pengaruh kinerja lingkungan, kepemilikan manajerial, kepemilikan institusional, komite audit dan dewan komisaris pada nilai perusahaan manufaktur yang terdaftar di Bursa Efek Indonesia (BEI) tahun $2014-2016$.

Secara teoretis, penelitian ini diharapkan mampu memberikan kontribusi pada studi akuntansi dengan memberikan bukti empiris mengenai pengaruh Kinerja Lingkungan dan komponen Good Corporate Governance (GCG) pada nilai perusahaan manufaktur yang terdaftar di Bursa Efek Indonesia (BEI) serta dapat dipergunakan untuk menambah wawasan dan ilmu pengetahuan. Bagi perusahaan 
yang diteliti, perusahaan dapat mengetahui dan memahami pentingnya pemenuhan legitimasi melalui Kinerja Lingkungan, serta meningkatkan implementasi komponen Good Corporate Governance (GCG) sebagai mekanisme untuk meminimalisir konflik keagenan yang terjadi di dalam perusahaan. Sinyal-sinyal yang dikeluarkan oleh perusahaan melalui laporan keuangan akan menjadi dasar investor untuk mengambil keputusan sehingga hal ini berpengaruh pada nilai perusahaan. Secara praktis, penelitian ini dapat dijadikan sebagai bahan pertimbangan dalam memperbaiki Kinerja Lingkungan dan meningkatkan implementasi komponen Good Corporate Governance bagi perusahaan. Bagi investor, penelitian ini dapat dijadikan sebagai bahan masukan di dalam berinvestasi dengan melihat kinerja lingkungan dan komponen good corporate governance pada perusahaan.

Teori sinyal adalah teori yang menjelaskan suatu tindakan yang dilakukan manajemen perusahaan dengan memberikan suatu petunjuk kepada stakeholders mengenai pandangan manajemen dalam melihat kondisi perusahaan di masa lampau, masa kini maupun masa yang akan datang. Sinyal yang ada pada laporan keuangan perusahaan, dapat berupa informasi lain atau promosi yang menyatakan bahwa perusahaan tersebut lebih baik daripada perusahaan lain (Budiharjo, 2016). Selain itu, perusahaan yang memiliki nilai yang tinggi cenderung memiliki laporan yang mudah dibaca dan dapat dibedakan dari perusahaan lainnya (Birjandi et al., 2015). Teori sinyal menyatakan bahwa manajer atau perusahaan secara kualitatif memiliki kelebihan informasi dibandingkan dengan pihak luar menggunakan ukuran-ukuran atau fasilitas tertentu yang menyiratkan kualitas perusahaannya 
(Gumanti, 2009). Informasi yang dikeluarkan oleh perusahaan merupakan hal yang penting, karena berpengaruh terhadap keputusan investasi pada pihak di luar perusahaan. Asimetri informasi akan terjadi ketika manajer lebih mengetahui informasi internal dan prospek perusahaan di masa yang akan datang dibandingkan dengan pemilik dan stakeholder lainnya (Barus dan Setiawati, 2015). Morris (1987) menyatakan, perusahaan lebih banyak memiliki informasi mengenai produk yang dijualnya daripada pembeli.

Pada awalnya masalah keagenan (agency problem) dieksplorasi oleh Ross (1973), dan eksplorasi teoretis pertama kali dilakukan secara mendetail tentang teori keagenan dikemukakan oleh Jensen and Meckling (1976) yang menyebutkan manajer sebagai "agent" dan pemegang saham sebagai "principal". Agen akan berupaya untuk melakukan tindakan yang kurang sesuai dengan keinginan prinsipal yaitu dengan melakukan praktik manajemen laba. Manajemen laba berarti laba yang diatur sedemikian rupa oleh manajer dan bukan laba sebenarnya, dimana tindakan tersebut dilandasi untuk memenuhi kepentingan pribadi agen (Nurwa, 2015). Para pemakai laporan keuangan akan salah mengambil keputusan yang diakibatkan oleh praktik manajemen laba sehingga hal ini mengakibatkan menurunnya nilai perusahaan. Nuswandari (2009) menyatakan bahwa teori keagenan digunakan untuk mengatasi permasalahan di dalam hubungan keagenan. Menurut Eisenhardt (1989), teori agensi memakai tiga asumsi sifat manusia. Pertama, manusia/individu cenderung lebih mementingkan kepentingan pribadinya daripada kepentingan yang dimiliki oleh orang lain (self interest behavior). Kedua, 
manusia mempunyai daya pikir yang terbatas tentang persepsi masa depan (bounded rationality) dan ketiga, manusia selalu menjauhi risiko (risk averse).

Suchman (1995) menyatakan bahwa legitimasi dianggap sebagai menyamakan asumsi bahwa suatu tindakan yang dilakukan oleh entitas merupakan tindakan yang diinginkan, pantas ataupun sesuai dengan budaya dan definisi yang dikembangkan secara sosial. Teori legitimasi menitikberatkan pada interaksi/hubungan antara perusahaan dengan masyarakat. Teori ini menyatakan bahwa perusahaan/organisasi adalah bagian dari masyarakat sehingga harus memperhatikan dan mematuhi norma-norma sosial yang berlaku di masyarakat. Deegan (2002) menyatakan bahwa dengan memperoleh legitimasi, perusahaan dapat melanjutkan aktivitas operasionalnya untuk jangka waktu ke depan.

Suratno dkk (2006) menyatakan bahwa kinerja lingkungan adalah kinerja perusahaan di dalam usaha menciptakan lingkungan yang baik. Berdasarkan situs Kementerian Lingkungan Hidup, peringkat kinerja lingkungan perusahaan dibagi menjadi 5 (lima) peringkat warna mulai dari yang terbaik, EMAS, HIJAU, BIRU, MERAH, sampai ke yang terburuk, HITAM. Peringkat tersebut sebagai bentuk kemudahan komunikasi dengan stakeholder dalam menyikapi hasil tanggung jawab lingkungan perusahaan. Asas Good Corporate Governance yaitu transparansi, akuntabilitas, responsibilitas, independensi serta kewajaran dan kesetaraan diperlukan untuk mencapai kesinambungan usaha (sustainability) perusahaan dengan memperhatikan pemangku kepentingan (stakeholders). Komponenkomponen yang terdapat di dalam Good Corporate Governance di dalam penelitian 
Agung Dewi Kurnia dan Pradnyantha Wirasedana. Pengaruh...

ini antara lain Kepemilikan Manajerial, Kepemilikan Institusional, Komite Audit dan Dewan Komisaris.

Kepemilikan manajerial adalah besarnya saham yang dimiliki manajemen dari total saham yang beredar. Kepemilikan manajerial juga berarti manajer di suatu perusahaan sebagai pemegang saham. Hal ini ditunjukkan dengan persentase kepemilikan saham perusahaan oleh manajer (Kusumaningtyas, 2015). Kepemilikan Institusional adalah besarnya jumlah saham yang dimiliki institusi dari total saham beredar. Adanya kepemilikan oleh institusional akan mendorong peningkatan pengawasan yang lebih optimal dimana monitoring melalui kepemilikan institusional tentunya akan menjamin kesejahteraan untuk pemegang saham (Sinarmayarani dan Suwitho, 2016). Komite Audit paling sedikit terdiri dari 3 (tiga) orang anggota yang berasal dari Komisaris Independen dan Pihak dari luar Emiten atau Perusahaan Publik serta diketuai oleh Komisaris Independen. Fama dan Jensen (1983) menyatakan bahwa komisaris independen berfungsi sebagai penengah jika terjadi perselisihan di antara para manajer internal, memberikan nasihat kepada manajemen dan mengawasi kebijakan manajemen. Wardhani (2006) menyatakan bahwa komisaris independen adalah anggota dewan komisaris yang tidak memiliki kekerabatan dengan manajemen, anggota dewan komisaris lain dan pemegang saham pengendali.

Berdasarkan teori legitimasi yang merupakan bentuk pengakuan keberadaan perusahaan dari masyarakat, perusahaan/organisasi harus dapat menyelaraskan antara kepentingan ekonomi dengan kepentingan lingkungan dan sosialnya. Apabila perusahaan menginginkan nilai perusahaan meningkat, maka perusahaan 
ISSN: 2302-8556

E-Jurnal Akuntansi Universitas Udayana

Vol.24.3.September (2018): 1737-1767

harus mampu meningkatkan kinerja/pengelolaan lingkungannya. Teori legitimasi menyatakan apabila perusahaan manufaktur mampu memperhatikan pengelolaan lingkungannya, maka keberadaan perusahaan tersebut akan direspon positif oleh masyarakat, sehingga citra perusahaan akan meningkat. Berdasarkan uraian tersebut maka diambil hipotesis sebagai berikut.

$\mathrm{H}_{1}$ : Kinerja Lingkungan berpengaruh positif pada nilai perusahaan.

Berdasarkan teori keagenan, adanya Good Corporate Governance, manajer dapat diawasi dengan baik dan agency cost dapat dikurangi. Secara teoretis, jika praktik Good Corporate Governance berjalan dengan efektif dan efisien maka seluruh proses aktivitas perusahaan akan berjalan dengan baik yang selanjutnya dapat meningkatkan nilai perusahaan, mengurangi risiko yang mungkin dilakukan oleh individu dengan keputusan yang menguntungkan diri sendiri. Good Corporate Governance juga dapat meningkatkan kepercayaan investor untuk menanamkan modalnya yang juga akan berdampak pada nilai perusahaan.

Adanya proporsi kepemilikan yang cukup tinggi maka manajer akan merasa ikut memiliki perusahaan sehingga akan berusaha semaksimal mungkin melakukan tindakan-tindakan yang dapat memaksimalkan kemakmurannya. Hal ini akan mempersatukan kepentingan manajer dengan pemegang saham yang tentunya akan menimbulkan dampak positif bagi kinerja perusahaan dan meningkatkan nilai perusahaan. Berdasarkan uraian tersebut maka dapat dibuat hipotesis sebagai berikut.

$\mathrm{H}_{2}$ : Kepemilikan Manajerial berpengaruh positif pada nilai perusahaan. 
Pada umumnya, kepemilikan institusional bertindak sebagai pihak yang memonitor perusahaan dan pada khususnya memonitor manajer dalam mengelola perusahaan. Investor institusional akan memantau secara profesional perkembangan investasi yang ditanamkan pada perusahaan dan memiliki tingkat pengendalian yang tinggi terhadap tindakan manajemen. Hal ini memperkecil potensi manajemen untuk melakukan kecurangan, dengan demikian maka dapat menyelaraskan kepentingan manajemen dan kepentingan stakeholders lainnya untuk meningkatkan nilai perusahaan. Maka hipotesis pada penelitian ini dapat dirumuskan sebagai berikut.

$\mathrm{H}_{3}$ : Kepemilikan Institusional berpengaruh positif pada nilai perusahaan.

Adanya pemahaman komite audit mengenai masalah serta hal-hal yang berisiko, maka potensi terjadinya kerugian khususnya dari segi finansial seperti penurunan nilai perusahaan dapat dihindarkan dan diminimalisir. Selain itu, dengan adanya sistem pengawasan terhadap kinerja auditor internal oleh komite audit, diharapkan mampu meninjau anggota manajemen perusahaan yang bertanggung jawab atas kesalahan atau kecurangan yang dapat mendatangkan kerugian keuangan bagi perusahaan. Maka hipotesis pada penelitian ini dapat dirumuskan sebagai berikut.

$\mathrm{H}_{4}$ : Komite Audit berpengaruh positif pada nilai perusahaan.

Semakin tinggi proporsi dewan komisaris independen maka semakin ketat pula kegiatan monitoring yang dilakukan. Oleh karena itu, masalah benturan kepentingan antar para manajer internal seperti penyalahgunaan aset perusahaan dan manipulasi transaksi perusahaan dapat dimonitor secara efektif. Dengan 
demikian, biaya keagenan perusahaan akan semakin kecil sehingga perusahaan akan semakin efisien yang pada akhirnya juga mampu meningkatkan nilai perusahaan. Maka hipotesis pada penelitian ini dapat dirumuskan sebagai berikut. $\mathrm{H}_{5}$ : Dewan Komisaris independen berpengaruh positif pada nilai perusahaan.

\section{METODE PENELITIAN}

Desain penelitian yang digunakan dalam penelitian ini adalah pendekatan kuantitatif asosiatif tipe kausalitas. Penelitian ini dilakukan pada perusahaan manufaktur yang terdaftar di Bursa Efek Indonesia (BEI) dan masuk Program Penilaian Peringkat Kinerja Perusahaan dalam Pengelolaan Lingkungan Hidup (PROPER) periode 2014-2016 dengan mengakses situs Indonesian Stock Exchange dan Kementerian Lingkungan Hidup. Obyek Penelitian di dalam penelitian ini adalah Nilai Perusahaan pada perusahaan manufaktur yang terdaftar di Bursa Efek Indonesia (BEI) periode 2014-2016. Adapun Nilai Perusahaan di dalam penelitian ini diukur menggunakan Tobin's $Q$, dimana data yang diperlukan adalah harga saham penutupan, jumlah saham beredar, total utang dan total aktiva perusahaan.

Berdasarkan situs Kementerian Lingkungan Hidup, sistem peringkat kinerja PROPER mencakup 5 warna peringkat yaitu emas artinya sangat sangat baik dengan skor 5, hijau artinya sangat baik dengan skor 4, biru artinya baik dengan skor 3, merah artinya buruk dengan skor 2 dan hitam artinya sangat buruk dengan skor 1. Kepemilikan manajerial tentu akan mendorong pihak manager untuk bertindak sejalan dengan keinginan pemegang saham dengan meningkatkan kinerja dan tanggung jawab dalam mencapai kemakmuran pemegang saham (Imanta, 2011). Rumus menghitung kepemilikan manajerial: 


$$
\mathrm{X}_{2}=\frac{\sum S M}{\sum S B}
$$

Keterangan:

$\mathrm{SM}=$ Saham yang dimiliki Manajemen

$\mathrm{SB}=$ Saham beredar

Jumlah kepemilikan institusional yang tinggi akan meningkatkan sistem kontrol perusahaan guna meminimalisasi tingkat kecurangan akibat tindakan oportunistik pihak manajer yang nantinya menyebabkan berkurangnya nilai perusahaan (Wida dan Suartana, 2014). Rumus menghitung kepemilikan institusional:

$$
\mathrm{X}_{3}=\frac{\sum S I}{\sum S B}
$$

Keterangan:

SI = Saham yang dimiliki Institusi

$\mathrm{SB}=$ Saham beredar

Komite audit dalam penelitian ini diukur menggunakan skala rasio melalui persentase anggota komite audit independen terhadap seluruh anggota komite audit (Isnanta, 2008 dalam Manik, 2011):

$$
\mathrm{X}_{4}=\frac{\sum \text { Anggota Komite Audit Independen }}{\sum \text { Seluruh Komite Audit }}
$$

Komisaris independen merupakan bagian dari dewan komisaris yang bertindak secara independen untuk menilai kinerja perusahaan (Sibarani, 2013 dalam Hartoyo, 2016). Komisaris independen adalah anggota dewan komisaris yang tidak memiliki kekerabatan dengan manajemen, anggota dewan komisaris lain dan pemegang saham pengendali serta bebas dari hubungan bisnis atau hubungan lainnya yang dapat mempengaruhi sikap independensinya (Dianawati dan Siti, 2016). Rumus menghitung dewan komisaris independen: 


$$
\mathrm{X}_{5}=\frac{\sum \text { Anggota Komisaris Independen }}{\sum \text { Seluruh Komisaris }}
$$

Nilai perusahaan merupakan nilai pasar atas surat berharga hutang dan ekuitas perusahaan yang beredar. Nilai perusahaan merupakan persepsi pemilik modal terhadap tingkat keberhasilan perusahaan yang banyak menghubungkannya dengan harga saham (Tjahjono, 2013). Tobin's $Q$ merupakan nilai pasar dari firm's assets dan replacement value of those assets (Setyawan, 2016). Salah satu alternatif yang digunakan dalam menilai nilai perusahaan adalah dengan menggunakan Tobin's $Q$ (Hartoyo, 2016) dengan menggunakan rumus:

$$
\text { Tobin's } Q=\frac{M V E+D E B T}{T A} \text {. }
$$

Keterangan:

Tobin's $Q=$ Nilai Perusahaan $(\mathrm{Y})$

MVE = Nilai Pasar Ekuitas (closing price saham X Jumlah Saham beredar)

DEBT $\quad=$ Total Utang Perusahaan

TA $\quad=$ Total Aktiva

Sugiyono (2017:136) menyatakan bahwa, populasi adalah wilayah generalisasi terdiri atas obyek/subyek yang mempunyai kualitas dan karakteristik tertentu yang ditetapkan oleh peneliti untuk dipelajari dan kemudian ditarik kesimpulannya. Populasi di dalam penelitian ini adalah seluruh perusahaan manufaktur yang terdaftar di Bursa Efek Indonesia (BEI) pada tahun 2014-2016. Sampel yang ditentukan di dalam penelitian ini adalah perusahaan manufaktur yang mendapatkan peringkat PROPER dari Kementrian Lingkungan Hidup dan perusahaan manufaktur yang terdaftar di Bursa Efek Indonesia (BEI) pada tahun 2014-2016.

Metode pengambilan sampel di dalam penelitian ini dilakukan dengan purposive sampling. Kriteria pertama, perusahaan sektor manufaktur yang 
menyajikan laporan keuangan secara berturut-turut tahun 2014-2016. Kriteria pertama dipilih dengan tujuan agar sampel yang digunakan dalam penelitian ini memiliki kelengkapan data yang dibutuhkan. Kriteria kedua, perusahaan sektor manufaktur yang menyajikan laporan keuangan dalam satuan Rupiah secara berturut-turut tahun 2014-2016. Kriteria kedua dipilih dengan tujuan agar hasil perhitungan nilai perusahaan pada sampel penelitian tidak terpengaruhi dengan nilai tukar mata uang yang tidak menentu. Kriteria ketiga, perusahaan sektor manufaktur yang melaporkan peringkat PROPER berturut-turut tahun 2014-2016. Kriteria ketiga dipilih dengan tujuan agar sampel yang digunakan sesuai dengan tujuan penelitian, yaitu untuk mengetahui pengaruh kinerja lingkungan pada nilai perusahaan.

Metode pengumpulan data yang digunakan dalam penelitian ini adalah metode dokumentasi. Adapun jenis data yang digunakan dalam penelitian ini adalah data kuantitatif. Pada penelitian ini, data kuantitatif yang diperlukan adalah kinerja lingkungan, good corporate governance, dan nilai perusahaan. Sumber data yang digunakan dalam penelitian ini adalah data sekunder (secondary data), yaitu sumber yang tidak langsung memberikan data kepada pengumpul data, misalnya melalui orang lain atau dokumen (Sugiyono, 2014:193). Data yang digunakan dalam penelitian ini adalah data-data keuangan dari laporan tahunan perusahaan manufaktur yang terdaftar di Bursa Efek Indonesia (BEI) pada tahun 2014-2016 yang diakses melalui situs Indonesian Stock Exchange serta data-data perusahaan yang mengikuti Program Penilaian Peringkat Kinerja Perusahaan dalam Pengelolaan Lingkungan Hidup (PROPER) yang diakses melalui situs 
Kementerian Lingkungan Hidup. Teknik yang digunakan adalah analisis regresi linier berganda. Analisis linier berganda diformulasikan sebagai berikut.

$$
Y=\alpha+\beta_{1} \cdot X_{1}+\beta_{2} \cdot X_{2}+\beta_{3} \cdot X_{3}+\beta_{4} \cdot X_{4}+\beta_{5} \cdot X_{5}+\varepsilon .
$$

\section{HASIL DAN PEMBAHASAN}

Penelitian ini dilakukan untuk mengetahui pengaruh kinerja lingkungan dan komponen GCG pada nilai perusahaan. Adapun GCG pada penelitian ini diukur melalui proporsi kepemilikan manajerial, kepemilikan institusional, komite audit dan dewan komisaris independen. Populasi dalam penelitian ini adalah seluruh perusahaan manufaktur yang terdaftar di Bursa Efek Indonesia (BEI). Perusahaanperusahaan tersebut kemudian diseleksi dengan menggunakan kriteria tertentu (purposive sampling) sehingga diperoleh sebanyak 43 perusahaan untuk dijadikan sampel yang bisa dilihat pada Tabel berikut.

Tabel 1.

\section{Proses Pemilihan Sampel}

\begin{tabular}{|c|c|c|c|c|c|}
\hline \multirow[b]{2}{*}{ No. } & \multirow[b]{2}{*}{ Kriteria } & \multicolumn{3}{|c|}{ Tahun } & \multirow{2}{*}{$\begin{array}{l}\text { Jumlah } \\
\text { Sampel }\end{array}$} \\
\hline & & 2014 & 2015 & 2016 & \\
\hline 1. & $\begin{array}{l}\text { Perusahaan sektor manufaktur } \\
\text { yang terdaftar di BEI periode } \\
\text { 2014-2016 }\end{array}$ & 137 & 142 & 143 & 422 \\
\hline 2. & $\begin{array}{l}\text { Perusahaan yang tidak } \\
\text { menyajikan laporan keuangan } \\
\text { secara berturut-turut periode } \\
2014-2016\end{array}$ & 8 & 7 & 13 & (28) \\
\hline 3. & $\begin{array}{lcr}\text { Perusahaan } & \text { yang } & \text { tidak } \\
\text { menyajikan laporan keuangan } \\
\text { dalam satuan } & \text { rupiah } & \text { secara } \\
\text { beruturut-turut } & \text { periode } & \text { 2014- } \\
2016 & & \end{array}$ & 28 & 26 & 25 & (79) \\
\hline 4. & $\begin{array}{l}\text { Perusahaan yang tidak } \\
\text { melaporkan peringkat PROPER } \\
\text { berturut-turut periode 2014-2016 }\end{array}$ & 58 & 66 & 62 & (186) \\
\hline & Total sampel penelitian & 43 & 43 & 43 & 129 \\
\hline
\end{tabular}


Hasil uji statistik deskriptif pada penelitian ini selanjutnya akan disajikan pada Tabel berikut.

\section{Tabel 2.}

Hasil Uji Statistik Deskriptif

\begin{tabular}{lccccc}
\hline Variabel & N & Minimum & Maximum & Mean & $\begin{array}{c}\text { Std. } \\
\text { Deviation }\end{array}$ \\
\hline Y & 129 & 0,33 & 18,64 & 2,74 & 3,50 \\
X1 & 129 & 2,00 & 5,00 & 3,12 & 0,52 \\
X2 & 129 & 0,00 & 0,82 & 0,03 & 0,13 \\
X3 & 129 & 0,00 & 1,00 & 0,74 & 0,21 \\
X4 & 129 & 0,40 & 1,00 & 0,96 & 0,13 \\
X5 & 129 & 0,33 & 1,00 & 0,46 & 0,15 \\
\hline
\end{tabular}

Sumber: Data diolah peneliti 2018

Pada tabel ditunjukkan bahwa jumlah data yang digunakan pada penelitian ini adalah 129 data amatan pada laporan keuangan perusahaan manufaktur. Ratarata variabel Nilai Perusahaan (Y) adalah sebesar 2,74 dan nilai standar deviasi sebesar 3,50 yang lebih tinggi dari nilai rata-rata menunjukkan bahwa terdapat variasi $\mathrm{Y}$ yang besar antara nilai minimum dan nilai maksimum. Nilai minimum dan maksimum Y adalah sebesar 0,33 dan 18,64. Rata-rata variabel Kinerja Lingkungan $\left(\mathrm{X}_{1}\right)$ adalah sebesar 3,12 dan nilai standar deviasi sebesar 0,52 yang lebih rendah dari nilai rata-rata menunjukkan bahwa terdapat variasi kinerja lingkungan yang kecil antara nilai minimum dan nilai maksimum, selain itu ratarata sebesar 3,12 mencerminkan bahwa perusahaan sudah mendapatkan peringkat standar PROPER sebesar 3 pada kinerja lingkungannya. Nilai minimum dan maksimum kinerja lingkungan sebesar 2,00 dan 5,00.

Rata-rata variabel Kepemilikan Manajerial $\left(\mathrm{X}_{2}\right)$ adalah sebesar 0,03 dan nilai standar deviasi sebesar 0,13 yang lebih tinggi dari nilai rata-rata menunjukkan bahwa terdapat variasi kepemilikan manajerial yang besar antara nilai minimum dan nilai maksimum. Nilai minimum dan maksimum kepemilikan manajerial 
ISSN: 2302-8556

E-Jurnal Akuntansi Universitas Udayana

Vol.24.3.September (2018): 1737-1767

adalah sebesar 0,00 dan 0,82. Rata-rata variabel Kepemilikan Institusional $\left(\mathrm{X}_{3}\right)$ adalah sebesar 0,74 dan nilai standar deviasi sebesar 0,21 yang lebih rendah dari nilai rata-rata menunjukkan bahwa terdapat variasi kepemilikan institusional yang kecil antara nilai minimum dan nilai maksimum. Nilai minimum dan maksimum kepemilikan institusional sebesar 0,00 dan 1,00. Rata-rata variabel Komite Audit $\left(\mathrm{X}_{4}\right)$ adalah sebesar 0,96 dan nilai standar deviasi sebesar 0,13 yang lebih rendah dari nilai rata-rata menunjukkan bahwa terdapat variasi kepemilikan institusional yang kecil antara nilai minimum dan nilai maksimum. Nilai minimum dan maksimum kepemilikan institusional adalah sebesar 0,40 dan 1,00. Rata-rata variabel Dewan Komisaris Independen $\left(\mathrm{X}_{5}\right)$ adalah sebesar 0,46 dan nilai standar deviasi sebesar 0,15 yang lebih rendah dari nilai rata-rata menunjukkan bahwa terdapat variasi dewan komisaris independen yang kecil antara nilai minimum dan nilai maksimum. Nilai minimum dan maksimum dewan komisaris independen adalah sebesar 0,33 dan 1,00.

Tabel 3.

Hasil Uji Normalitas

\begin{tabular}{llc}
\hline & & $\begin{array}{c}\text { Unstandardized } \\
\text { Residual }\end{array}$ \\
\hline $\mathrm{N}$ & Mean & 129 \\
Normal Parameters $^{\mathrm{a}, \mathrm{b}}$ & Std. Deviation & 0,0000000 \\
& Absolute & 0,86186068 \\
Most Extreme & Positive & 0,120 \\
Differences & Negative & 0,120 \\
& & $-0,069$ \\
$\mathrm{~N}$ & & 129 \\
Kolmogorov-Smirnov Z & & 1,358 \\
Asymp. Sig. (2-tailed) & & 0,050 \\
\hline
\end{tabular}

Sumber: Data diolah peneliti 2018

Berdasarkan hasil uji normalitas, dapat diketahui bahwa semua data variabel yang digunakan dalam penelitian ini memiliki nilai probabilitas yang lebih besar 
dari taraf signifikansi $(\alpha=0,05)$ sehingga dapat disimpulkan bahwa keseluruhan data-data rasio keuangan berdistribusi normal.

Tabel 4.

Hasil Uji Multikolonieritas

\begin{tabular}{llcccc}
\hline \multicolumn{1}{c}{ Variabel } & & T & Sig. & \multicolumn{2}{c}{ Collinearity Statistics } \\
\cline { 5 - 6 } & & & & Tolerance & VIF \\
\hline Kinerja Lingkungan & X1 & 1,997 & 0,048 & 0,983 & 1,017 \\
Kepemilikan Manajerial & X2 & 1,068 & 0,288 & 0,631 & 1,585 \\
Kepemilikan Institusional & X3 & 1,912 & 0,058 & 0,629 & 1,591 \\
Komite Audit & X4 & 0,483 & 0,630 & 0,898 & 1,113 \\
Dewan Komisaris Independen & X5 & 2,799 & 0,006 & 0,934 & 1,070 \\
\hline
\end{tabular}

Sumber: Data diolah peneliti 2018

Berdasarkan hasil uji multikolonieritas, keseluruhan nilai variabel yang digunakan pada penelitian ini memiliki nilai tolerance yang lebih besar dari 0,100 dan nilai VIF yang lebih rendah dari 10,00 maka dapat disimpulkan bahwa tidak terdapat korelasi antara variabel bebas yang digunakan pada penelitian ini.

Tabel 5.

Hasil Uji Autokorelasi

\begin{tabular}{lccccr}
\hline Model & $\mathbf{R}$ & $\begin{array}{c}\text { R } \\
\text { Square }\end{array}$ & $\begin{array}{c}\text { Adjusted } \\
\text { R Square }\end{array}$ & $\begin{array}{c}\text { Std. Error } \\
\text { of the } \\
\text { Estimate }\end{array}$ & $\begin{array}{l}\text { Durbin- } \\
\text { Watson }\end{array}$ \\
\hline 1 & $0,348^{\mathrm{a}}$ & 0,121 & 0,085 & 3,3520783 & 2,022 \\
\hline Sumber: Data diolah peneliti 2018 & & &
\end{tabular}

Berdasarkan hasil uji autokorelasi, diperoleh nilai durbin-watson (dw) sebesar 2,022 yang berada diatas 1,000 dan dibawah 3,000 sehingga dapat disimpulkan bahwa tidak terdapat autokorelasi. 
ISSN: 2302-8556

E-Jurnal Akuntansi Universitas Udayana

Vol.24.3.September (2018): 1737-1767

Tabel 6.

Hasil Uji Heteroskedastisitas

\begin{tabular}{crrrrr}
\hline Model & \multicolumn{2}{c}{$\begin{array}{c}\text { Unstandardized } \\
\text { Coefficients }\end{array}$} & $\begin{array}{c}\text { Standardized } \\
\text { Coefficients }\end{array}$ & \multicolumn{1}{l}{ T } & Sig. \\
\cline { 2 - 6 } & \multicolumn{1}{c}{ B } & \multicolumn{1}{c}{ Std. } & \multicolumn{1}{c}{ Beta } \\
Error & & & \\
\hline 1 (Constant) & 2,142 & 3,349 & $-0,013$ & $-0,075$ & 0,526 \\
X1 & $-0,397$ & 5,276 & 0,031 & 0,191 & 0,840 \\
X2 & $2,068 \mathrm{E}-6$ & 0,000 & 0,097 & 0,590 & 0,558 \\
X3 & 0,091 & 0,154 & $-0,182$ & $-1,004$ & 0,321 \\
X4 & $-1,956$ & 1,947 & 0,200 & 1,223 & 0,229 \\
X5 & 0,357 & 0,292 & & & \\
\hline
\end{tabular}

Sumber: Data diolah peneliti 2018

Berdasarkan hasil uji heteroskedastisitas, keseluruhan variabel penelitian memiliki nilai sig yang lebih besar dari 0,05 sehingga dapat disimpulkan bahwa tidak terdapat gejala heteroskedastitas pada variabel yang digunakan pada penelitian ini.

Tabel 7.

Hasil Uji F

\begin{tabular}{llrrrrr}
\hline Model & & $\begin{array}{c}\text { Sum of } \\
\text { Squares }\end{array}$ & Df & $\begin{array}{c}\text { Mean } \\
\text { Square }\end{array}$ & F & Sig. \\
\hline \multirow{2}{*}{1} & Regression & 190,056 & 5 & 38,011 & 3,383 & $0,007^{\mathrm{b}}$ \\
& Residual & 1382,081 & 123 & 11,236 & & \\
& Total & 1572,137 & 128 & & & \\
\hline
\end{tabular}

Sumber: Data diolah peneliti 2018

Pada hasil uji $\mathrm{F}$, nilai signifikansi $\mathrm{F}=0,007$ tersebut lebih kecil dari taraf signifikansi 0,05. Berdasarkan hal tersebut, maka dapat disimpulkan bahwa terdapat pengaruh variabel bebas yakni kinerja lingkungan, kepemilikan manajerial, kepemilikan institusional, komite audit, dan dewan komisaris independen pada variabel terikat yakni nilai perusahaan, sehingga model penelitian ini dapat dikatakan layak untuk diteliti dan dapat dilanjutkan dengan pembuktian hipotesis. 
Tabel 8.

Hasil Uji t

\begin{tabular}{|c|c|c|c|c|c|}
\hline \multirow[t]{2}{*}{ Variabel } & \multicolumn{2}{|c|}{$\begin{array}{l}\text { Unstandardized } \\
\text { Coefficients }\end{array}$} & \multirow{2}{*}{$\begin{array}{c}\begin{array}{c}\text { Standardized } \\
\text { Coefficients }\end{array} \\
\text { Beta } \\
\end{array}$} & \multirow[t]{2}{*}{ t } & \multirow[t]{2}{*}{ Sig. } \\
\hline & $\mathbf{B}$ & Std. Error & & & \\
\hline (Constant) & $-7,143$ & 3,080 & & $-2,319$ & 0,022 \\
\hline $\mathrm{X} 1$ & 1,158 & 0,580 & 0,170 & 1,997 & 0,048 \\
\hline $\mathrm{X} 2$ & 3,084 & 2,887 & 0,114 & 1,068 & 0,288 \\
\hline $\mathrm{X} 3$ & 3,442 & 1,801 & 0,204 & 1,912 & 0,058 \\
\hline $\mathrm{X} 4$ & 1,145 & 2,370 & 0,043 & 0,483 & 0,630 \\
\hline $\mathrm{X} 5$ & 5,558 & 1,986 & 0,245 & 2,799 & 0,006 \\
\hline
\end{tabular}

Berdasarkan hasil uji t, disajikan nilai t dan sig dari masing-masing variabel bebas yang digunakan pada penelitian ini. Nilai t hitung untuk variabel $\mathrm{X}_{1}$ sebesar 1,997. Nilai t tabel sebesar 1,979 ditelusuri dengan nilai df $=0,025$ dan df $2=123$. Oleh karena nilai t hitung lebih besar dari t tabel maka dapat disimpulkan bahwa kinerja lingkungan berpengaruh pada nilai perusahaan dengan nilai yang positif. Nilai signifikansi kinerja lingkungan adalah sebesar 0,048 yang lebih rendah dari tingkat signifikansi 0,05 yang berarti bahwa kinerja lingkungan berpengaruh signifikan pada nilai perusahaan. Hasil penelitian ini sesuai dengan penelitian yang dilakukan oleh Hariati dan Rihatinigtyas (2015) serta Lingga dan Suaryana (2017) yang menyatakan bahwa kinerja lingkungan berpengaruh positif pada nilai perusahaan.

Nilai t hitung untuk variabel $\mathrm{X}_{2}$ sebesar 1,068. Nilai t tabel sebesar 1,979 ditelusuri dengan nilai df $=0,025$ dan df $2=123$. Nilai sig 0.288 lebih tinggi dari 0,05. Oleh karena nilai t hitung lebih rendah dari t tabel maka dapat disimpulkan bahwa secara tidak signifikan, kepemilikan manajerial tidak berpengaruh pada nilai perusahaan. Hasil penelitian ini sejalan dengan penelitian yang dilakukan oleh Dewi dan Suardana (2015) bahwa kepemilikan manajerial yang sangat rendah dapat 
menyebabkan manajer merasa hanya berfungsi sebagai pegawai dari pemilik mayoritas dimana setiap keinginan manajemen akan dipengaruhi oleh keinginan pemilik mayoritas perusahaan. Nilai t hitung untuk variabel $X_{3}$ sebesar 1,912 . Nilai $\mathrm{t}$ tabel sebesar 1,979 ditelusuri dengan nilai $\mathrm{df}=0,025 \mathrm{dan} \mathrm{df} 2=123$. Nilai sig 0.058 lebih tinggi dari 0,05. Oleh karena nilai t hitung lebih rendah dari t tabel maka dapat disimpulkan bahwa secara tidak signifikan, kepemilikan institusional tidak berpengaruh pada nilai perusahaan. Hasil penelitian ini bertentangan dengan hasil penelitian yang dilakukan oleh Cornett et al., (2007), Nur'aeni (2010), Muyarti dan Suardikha (2014) serta Wida dan Suartana (2014) yang menyatakan bahwa kepemilikan institusional berpengaruh pada nilai perusahaan.

Nilai t hitung untuk variabel $\mathrm{X}_{4}$ sebesar 0,483 . Nilai t tabel sebesar 1,979 ditelusuri dengan nilai $\mathrm{df}=0,025$ dan $\mathrm{df} 2=123$. Nilai sig 0.63 lebih tinggi dari 0,05 . Oleh karena nilai t hitung lebih rendah dari t tabel maka dapat disimpulkan bahwa secara tidak signifikan, komite audit tidak berpengaruh pada nilai perusahaan. Penelitian ini sejalan dengan penelitian yang dilakukan oleh Wardoyo dan Veronica (2013) yang menyatakan bahwa keberadaan komite audit bukan merupakan jaminan bahwa kinerja perusahaan akan semakin baik, sehingga pasar menganggap keberadaan komite audit bukanlah faktor yang mereka pertimbangkan dalam mengapresiasi nilai perusahaan. Nilai t hitung untuk variabel $\mathrm{X}_{5}$ adalah sebesar 2,799 dengan nilai yang positif. Nilai t tabel sebesar 1,979 ditelusuri dengan nilai df $=0,02$ dan df $2=123$. Nilai sig 0.006 lebih rendah dari 0,05 . Oleh karena nilai $t$ hitung lebih tinggi dari t tabel maka dapat disimpulkan bahwa secara signifikan, dewan komisaris independen berpengaruh pada nilai perusahaan. Hasil penelitian 
ini sesuai dengan penelitian yang dilakukan oleh Muyarti dan Suardhika (2014) serta Hariati dan Rihatinigtyas (2015) yang menyatakan bahwa dewan komisaris independen berpengaruh positif pada nilai perusahaan.

Tabel 9.

Hasil Uji Koefisien Determinasi

\begin{tabular}{lcccc}
\hline Model & $\mathbf{R}$ & R Square & $\begin{array}{c}\text { Adjusted R } \\
\text { Square }\end{array}$ & $\begin{array}{c}\text { Std. Error of the } \\
\text { Estimate }\end{array}$ \\
\hline 1 & $0,348^{\mathrm{a}}$ & 0,121 & 0,085 & 3,3520783 \\
a. Predictors: (Constant), X5, X1, X3, X4, X2 & & \\
\hline
\end{tabular}

Sumber: Data diolah peneliti 2018

Koefisien determinasi sama dengan satu berarti variabel independen berpengaruh secara sempurna terhadap variabel dependen dan jika koefisien determinasi $=0$ berarti variabel independen tidak berpengaruh terhadap variabel dependen (Ghozali, 2016:95). Berdasarkan hasil uji koefisien determinasi $\left(\mathrm{R}^{2}\right)$, maka diperoleh hasil $\mathrm{R}$ sebesar 0,348 . Hal ini menunjukkan hubungan yang lemah antara kinerja lingkungan dan komponen good corporate governance pada nilai perusahaan. Nilai adjusted $\mathrm{R}^{2}$ adalah 0,085 hal ini berarti berarti $8,5 \%$ variabel bebas Nilai Perusahaan yang dapat dijelaskan oleh variasi lima variabel independen, yakni Kinerja Lingkungan, Kepemilikan Manajerial, Kepemilikan Institusional, Komite Audit dan Dewan Komisaris Independen sedangkan sisanya $(100 \%-8,5 \%=91,5 \%)$ dijelaskan oleh sebab-sebab lain di luar model.

Penelitian ini diharapkan dapat memberikan kontribusi pada studi akuntansi dan pemahaman mengenai pengaruh kinerja lingkungan dan komponen Good Corporate Governance pada nilai perusahaan manufaktur yang terdaftar di Bursa Efek Indonesia. Penelitian ini diharapkan dapat memberikan masukan bagi penelitipeneliti lain agar dapat mengetahui dan memahami teori-teori yang ada dengan realita yang sebenarnya dalam suatu perusahaan, serta penelitian ini dapat 
ISSN: 2302-8556

E-Jurnal Akuntansi Universitas Udayana

Vol.24.3.September (2018): 1737-1767

dipergunakan untuk menambah wawasan dan ilmu pengetahuan. Penelitian ini juga membuktikan bahwa tidak semua variabel yang digunakan secara teori memengaruhi nilai perusahaan ketika penelitian berpengaruh secara nyata. Hal ini dimungkinkan terjadi karena adanya perbedaan periode penelitian, obyek penelitian, dan kondisi yang berbeda. Penelitian ini dapat memberikan implikasi bagi perusahaan sebagai bahan pertimbangan dalam memperbaiki kinerja lingkungan dan meningkatkan implementasi komponen Good Corporate Governance pada nilai perusahaan. Bagi investor, penelitian ini dapat dijadikan sebagai bahan masukan di dalam melakukan keputusan investasi dengan melihat kinerja lingkungan dan komponen good corporate governance pada perusahaan.

\section{SIMPULAN}

Berdasarkan hasil analisis data, maka dapat ditarik kesimpulan yaitu kinerja lingkungan berpengaruh positif pada nilai perusahaan. Hal ini berarti semakin baik kinerja lingkungan yang dilakukan perusahaan akan dapat menarik para investor karena telah mendapatkan kepercayaan dari masyarakat sehingga hal ini dapat meningkatkan nilai perusahaan. Kepemilikan manajerial tidak berpengaruh pada nilai perusahaan. Hal ini berarti kepemilikan manajerial yang rendah, tidak mempengaruhi naik turunnya nilai perusahaan karena kepemilikan manajerial yang rendah menyebabkan manajer kurang bertindak secara produktif di dalam meningkatkan nilai perusahaan. Kepemilikan institusional tidak berpengaruh pada nilai perusahaan. Kepemilikan institusional yang hanya berfokus pada laba saat ini dan jika laba saat ini tidak memberikan keuntungan yang baik oleh pihak institusional, memungkinkan pihak institusional menarik sahamnya dari 
perusahaan dan mengakibatkan penurunan terhadap harga saham perusahaan. Komite audit tidak berpengaruh pada nilai perusahaan. Hal ini berarti jumlah anggota komite audit independen bukan merupakan suatu jaminan bahwa kinerja suatu perusahaan akan juga akan meningkat. Dewan komisaris independen berpengaruh positif pada nilai perusahaan. Hal ini berarti semakin tinggi proporsi dewan komisaris independen maka semakin ketat pula kegiatan monitoring yang dilakukan.

Berdasarkan simpulan yang disampaikan di atas, saran yang dapat diajukan adalah, hasil penelitian ini membuktikan bahwa kinerja lingkungan dan dewan komisaris independen berpengaruh positif pada nilai perusahaan. Diharapkan kepada perusahaan agar selalu mengelola tanggung jawab lingkungannya dengan baik dan menjaga keberadaan dewan komisaris independen dalam mengawasi kegiatan operasional perusahaan sehingga kinerja perusahaan akan mengalami peningkatan yang berpengaruh pada nilai perusahaan di mata investor.

\section{REFRENSI}

Aghashahi, Betsabeh, Ashkan Davarpanah, Rosmini Omar, dan Majid Sarli. 2013. The Relationship between Leadership Style and Organizational Commitment: A Survey in Malaysian Contract Centre. Interdiciplinary Journal of Research in Business. International Business School, 2(11), pp.01-07.

Barus, Andreani Caroline dan Kiki Setiawati. 2015. Pengaruh Asimetri Inforamasi, Mekanisme Corporate Governance, dan Beban Pajak Tangguhan terhadap Manajemen Laba. Jurnal Wira Ekonomi Mikroskil Program Studi Akuntansi STIE Mikroskil, 5 (1), hal.31-40.

Birjandi, Hakemi, and Sadeghi. 2015. The Study Effect Agency Theory and Signalling Theory on The Level of Voluntary Disclosure of Listed Companies in Tehran Stock Exchange. Reseacrh Journal of Finance and Accounting, 6 (1), pp.174-183.

Budiharjo, Roy. 2016. Pengaruh Good Corporate Governance terhadap Return 
Saham dengan Profitabilitas sebagai Variabel Intervening dan Moderating (Studi Empiris pada Perusahaan Peraih CGPI yang Terdaftar di Bursa Efek Indonesia tahun 2010-2012). Jurnal TEKUN Universitas Mercu Buana, 7 (3), hal.80-98.

Cornett, Alan, Anthony dan Hassan Tehranian. 2007 The Impact of Institusional Ownership on Corporate Operating Performance. Journal of Banking and Finance, 31 (7), pp.1771-1794

Danarwati, Yanti Sri. 2013. Tujuan Memaksimumkan Nilai Perusahaan. Jurnal Sekolah Tinggi Ilmu Administrasi ASMI SOLO, hal.1-9.

Deegan, Craig. 2002. The Legitimising Effect of Social and Environmental Disclosure - A Theoritical Foundation. Accounting, Auditing and Accountability Journal, 15 (3), pp.282-311.

Dewi, Lini Novita dan Ketut Alit Suardana. 2015. Pengaruh Keputusan Investasi dan Good Corporate Governance pada Kinerja Keuangan serta Implikasinya pada Nilai Perusahaan. E-Jurnal Akuntansi Universitas Udayana, 12 (3), hal.786-802.

Dewi, Ni Luh Putu Apriliani Candra. 2016. Pengaruh Kinerja Keuangan dan Nilai Perusahaan Terhadap Keberlanjutan Usaha (Going Concern) dengan Corporate Social Responsibility (CSR) Disclosure sebagai Variabel Intervening pada Perusahaan Perbankan di Bursa Efek Indonesia (BEI). Skripsi, Sarjana Ekonomi Akuntansi pada Fakultas Ekonomi dan Bisnis Universitas Pendidikan Nasional, Denpasar.

Dianawati, Cici Putri dan Siti Rokhmi Fuadati. 2016. Pengaruh CSR dan GCG terhadap Nilai Perusahaan: Profitabilitas sebagai Variabel Intervening. Jurnal Ilmu Riset dan Manajemen Sekolah Tinggi Ilmu Ekonomi Indonesia (STIESIA), 5 (1), hal.1-20.

Eisenhardt, Kathleen M. 1989. Building Theories from Case Study Research. The Academy of Management Review, 14 (4), pp.532-550.

Fama, Eugene F. dan Michael C. Jensen. 1983. Agency Problems and Residual Claims. Journal of Law and Economics. The University of Chicago Press, 62 (2), hal.327-349.

Gumanti, Tatang A. 2009. Teori Sinyal dalam Manajemen Keuangan. Artikel Dosen Fakultas Ekonomi pada Universitas Jember.

Ghozali, Imam H. 2016. Aplikasi Analisis Multivariete dengan Program IBM SPSS 23. Semarang: Universitas Diponegoro.

Hariati, Isnin dan Yeney Widya Rihatiningtyas. 2015. Pengaruh Tata Kelola Perusahaan dan Kinerja Lingkungan terhadap Nilai Perusahaan. Simposium 
Nasional Akuntansi XVIII, Medan.

Herawaty, Vinola. 2008. Peran Praktek Corporate Governance sebagai Moderating Variable dari Pengaruh Earnings Management terhadap Nilai Perusahaan. Jurnal Bisnis dan Akuntansi STIE Trisakti, 10 (2), hal.97-108.

Hartoyo. 2016. Analisis Pengaruh Profitabilitas, Pengungkapan Corporate Social Responsibility, dan Corporate Governance terhadap Nilai Perusahaan. Skripsi Sarjana Jurusan Akuntansi Fakultas Ekonomi dan Bisnis Universitas Muhammadiyah, Surakarta.

Imanta, Dea. 2011. Faktor-faktor yang Mempengaruhi Kepemilikan Manajerial. Jurnal Bisnis dan Akuntansi STIE Trisakti, 13 (1), hal.67-80.

Indriani, Jaka Darmawan, dan Siti Nurhawa. 2014. Analisis Manajemen Laba terhadap Nilai Perusahaan yang Terdaftar di Bursa Efek Indonesia (Studi Khusus: Perusahaan Dagang Otomotif). Jurnal Akuntansi dan Keuangan Universitas Bina Darma, 5 (1), hal.19-32.

Jensen, Michael C. dan William H. Meckling. 1976. Theory of Firm; Managerial Behavior, Agency Cost, and Ownership Structure. Journal of Financial Economics Harvard University, 3 (4), pp.305-360.

Kusumaningtyas, Metta. 2014. Pengaruh Ukuran Komite Audit dan Kepemilikan Institusional terhadap Manajemen Laba. Jurnal Prestasi STIE Bank BPD Jateng, 13 (1), hal.82-96.

Kusumaningtyas, Titah Kinanti. 2015. Pengaruh Good Corporate Governance terhadap Nilai Perusahaan yang Terdaftar pada Indeks Sri-Kehati. Jurnal Ilmu dan Riset Akuntansi Sekolah Tinggi Ilmu Ekonomi Indonesia (STIESIA) Surabaya, 4 (7), hal.1-15

Kusumawardani, Ira dan I Putu Sudana. 2017. Faktor-Faktor yang Memengaruhi Pengungkapan Corporate Social Responsibility. E-Journal Akuntansi Universitas Udayana, 19 (1), hal.741-770.

Lingga, Winayaka dan I Gusti Ngurah Agung Suaryana. 2017. Pengaruh Langsung dan Tidak Langsung Kinerja Lingkungan pada Nilai Perusahaan. E-jurnal Akuntansi Univeritas Udayana, 20 (2), hal.1419-1445.

Manik, Tumpal. 2011. Analisis Pengaruh Kepemilikan Manajemen, Komisaris Independen, Komite Audit, Umur Perusahaan terhadap Kinerja Keuangan (Studi Empiris Perusahaan Property \& Real Estate di BEI). JEMI Universitas Maritim Raja Hali Aji, 2 (2), hal.25-53.

Muryati, Ni Nyoman Tri Sariri dan I Made Sadha Suardikha. 2014. Pengaruh Corporate Governance pada Nilai Perusahaan. E-Jurnal Akuntansi 
Universitas Udayana, 9 (2), hal. 411-429.

Morris, Richard D. 1987. Signalling, Agency Theory, and Accounting Policy Choice. Accounting and Business Research, 18 (69), pp.47-56.

Narwal, Karwam Pal dan Sonia Jindal. 2015. The Impact of Corporate Governance on the Profitability: An Empirical Study of Indian Textile Industry. International Journal of research in Management, Science and Technology Guru Jambheshwar University, 3 (2), pp.81-85.

Nurwa, Risha Aristiani. 2015. Pengaruh Kualitas Laba Akuntansi terhadap Efisiensi Investasi Perusahaan dengan Risiko Litigasi sebagai Variabel Moderating. Skripsi Sarjana Ekonomika Akuntansi pada Fakultas Ekonomika dan Bisnis Universitas Diponegoro, Semarang.

Nur'aeni, Dini. 2010. Pengaruh Struktur Kepemilikan Saham terhadap Kinerja Perusahaan (Studi Kasus pada Perusahaan Manufaktur yang Listing di Bursa Efek Indonesia). Skripsi Sarjana Fakultas Ekonomi pada Universitas Diponegoro, Semarang.

Nuswandari, Cahyani. 2009. Pengaruh Good Corporate Governance Perception Index terhadap Kinerja Perusahaan pada Perusahaan yang Terdaftar di Bursa Efek Jakarta. Jurnal Bisnis dan Ekonomi (JBE) Fakultas Ekonomi Universitas Stikubank Semarang, 16 (2), hal.70-84.

Oktalia, Dwi. 2014. Pengaruh Kinerja Lingkungan dan Profitabilitas terhadap Corporate Social Responsibility Disclosure dalam Laporan Tahunan Perusahaan (Studi Empiris pada Perusahaan Go Public yang Terdaftar di BEI 2009-2012). Artikel Sarjana Ekonomi pada Fakultas Ekonomi Universitas Negeri Padang.

Rahmatia, Tri Lasita dan Andayani. 2015. Pengaruh Kepemilikan Manajerial terhadap Nilai Perusahaan: Tanggung Jawab Sosial sebagai Variabel Moderating. Jurnal Ilmu dan Riset Akuntansi Sekolah Tinggi Ilmu Ekonomi Indonesia (STIESIA) Surabaya, 4 (3), hal. 1-15.

Rahmatwati, Yuliana. 2017. Konflik dan Kerusakan Lingkungan (Pembangunan Pabrik Semen di Rembang). https://www.kompasiana.com/yelinrahmatwati/konflik-dan-kerusakanlingkungan-pembangunan-pabrik-semen-dirembang_58e336fac223bdff0d177295. Diakses 28 November 2017

Rakhiemah, Aldilla Noor dan Dian Agustia. 2009. Pengaruh Kinerja Lingkungan terhadap Corporate Social Responsibility (CSR) Disclosure dan Kinerja Finansial Perusahaan Manufaktur yang Terdaftar di Bursa Efek Indonesia. Jurnal Skripsi Universitas Airlangga. 
Siallagan, Hamonangan dan Mas'ud Machfoeds. 2006. Mekanisme Corporate Governance, Kualitas Laba dan Nilai Perusahaan. Simposium Nasional Akuntansi IX Padang, 23-26 Agustus 2006.

Sinarmayarani, Adhita dan Suwitho. 2016. Pengaruh Kepemilikan Institusional dan Profitabilitas terhadap Nilai Perusahaan melalui Kebijakan Dividen. Jurnal Ilmu dan Riset Manajemen Sekolah Tinggi Ilmu Ekonomi Indonesia (STIESIA) Surabaya, 5 (5), hal.1-18.

Sitepu, Rehulina Novi. 2015. Pengaruh Kebijakan Deviden, Kebijakan Leverage, dan Profitabilitas terhadap Nilai Perusahaan. (Perusahaan Manufaktur yang Terdaftar di BEI pada Tahun 2009-2013). Thesis Sarjana Fakultas Ekonomi pada Universitas Atma Jaya, Jogjakarta.

Setyawan, Budi. 2016. Pengaruh Corporate Social Responsibility dan Good Coporate Governance terhadap Nilai Perusahaan (Studi pada Sektor Pertambangan di Bursa Efek Indonesia). Jurnal Universitas Pamulang. hal.498-527

Suaryana, Agung. 2011. Implementasi Akuntansi Sosial Dan Lingkungan Di Indonesia. E-Jurnal Akuntansi Fakultas Ekonomi Universitas Udayana. hal.1-26

Suchman, Mark C. 1995. Managing Legitimacy: Strategic and Institusional Approach. The Academy Management Review University of WisconsinMadison, 20 (3), pp.571-610.

Sugiyono. 2014. Metode Penelitian Bisnis (Pendekatan Kuantitatif, Kualitatif, dan $R \& D)$. Bandung: Alfabeta.

Sugiyono. 2017. Metode Penelitian Bisnis Pendekatan Kuantitatif, Kualititatif Kombinasi, dan $R \& D$. Bandung: Alfabeta.

Suratno, Darsono, Siti Mutmainah. 2006. Pengaruh Environmental Performance terhadap Enviromental Disclosure dan Economis Performance (Studi Empiris pada Perusahaan Manufaktur yang Terdaftar di Bursa Efek Jakarta Periode 2001-2004). Simposium Nasional Akuntansi IX Padang. 23-26 Agustus 2006.

Susanti, Rina dan Titik Mildawati. 2014. Pengaruh Kepemilikan Manajemen, Kepemilikan Institusional dan Corporate Social Responsibility terhadap Nilai Perusahaan. Jurnal Ilmu dan Riset Akuntansi Sekolah Tinggi Ilmu Ekonomi Indonesia (STIESIA) Surabaya, 3 (1), hal.1-17.

Tjahjono, Mazda Eko Sri. 2013. Pengaruh Kinerja Lingkungan terhadap Kinerja Perusahaan dan Kinerja Keuangan. Jurnal Ekonomi Universitas Sultan Ageng Tirtayasa, 4 (1), hal.38-46. 
ISSN: 2302-8556

E-Jurnal Akuntansi Universitas Udayana

Vol.24.3.September (2018): 1737-1767

Wardoyo dan Theodora Martina Veronica. 2013. Pengaruh Good Corporate Governance, Corporate Social Responsibility \& Kinerja Keuangan terhadap Nilai Perusahaan. Jurnal Dinamika Manajemen Fakultas Ekonomi Univeristas Gunadarma, Jakarta, 4(2), hal.132-149.

Wardhani, Ratna. 2006. Mekanisme Corporate Governance dalam Perusahaan yang Mengalami Permasalahan Keuangan. Simposium Nasional Akuntansi IX Padang. 23-26 Agustus 2006.

Wida, P. D, Ni Putu dan I Wayan Suartana. 2014. Pengaruh Kepemilikan Manajerial dan Kepemilikan Institusional pada Nilai Perusahaan. E-Jurnal Akuntansi Universitas Udayana, 9 (3), hal.570-590. 